\title{
ON THE SEVIRI AUGUSTALES AS AGENTS OF ROMANITY IN HISPANIA ${ }^{1}$
}

\author{
Barrón Ruiz de la Cuesta, Alberto 2 \\ https://doi.org/10.18778/8220-421-6.15
}

\begin{abstract}
This chapter analyses the general features of the seviratus Augustalis, its territorial presence and continuity in the Roman Empire, and its influence in the spreading of the cultural and religious Roman customs in Hispania, through the study of its preserved epigraphic sources. The seviratus Augustalis was especially developed in the Western towns of the Empire, it lasted from the $1^{\text {st }}$ to the $3^{\text {rd }}$ century $A D$, and it was a semi-official institution mainly held by wealthy freedmen looking for social recognition. Despite the unresolved debate about its concrete function, the numerous preserved inscriptions in relation to the Augustality provide important information about the religious and munificent actions of its members. From the study of the existing epigraphic inscriptions in Hispania, we will demonstrate the role played by the seviri Augustales as promoters of Romanity, based on elements such as the worship of Roman deities, the connection of different gods with the emperor, the diffusion of Latin onomastics, the adoption of Roman magistracies and the imitation of the local Romanised elites. Consequently, this position created in Italy worked in Hispania as a diffusor of the Roman religion and the Roman social order, promoting the consolidation of the imperial regime in the provinces.
\end{abstract}

1 This paper has been written within the framework of the project HAR2017-84711-P of the Spanish National Plan of Research.

2 University of Cantabria, Department of Historical Sciences, Postdoctoral Researcher. Av. Los Castros s/n, 39005 Santander (Spain). barronal@unican.es. 
Keywords: seviri Augustales, Romanitas, Latin Epigraphy, Hispania, Roman Spain.

Throughout history, Rome and Iberia have often been connected in different cultural features, and the Roman period is one of the main examples of that relation. This study focuses on a particular aspect that shows the vast influence of Italy over Hispania after the Roman conquest. The Roman Republic, and the Empire later, not only controlled their provincial territories, but they also transformed them into new dynamic areas of the Roman world. The provinces became part of the Romanitas or Romanity, understood as "the culture, civilization, way of life, et cetera, of the ancient Romans" and "the fact of being Roman, or of having adopted Roman customs or institutions" (OED 2010). That was one of the keys of the adaptability and the long-term existence of the Roman Empire, whose cultural impact remains to this day.

In relation to this global process of acculturation, we will expound the importance of the seviratus Augustalis as an institution that contributed to the development of the Romanity in Hispania, reinforced the socio-political system created and maintained by the Romans since their arrival in Hispania, and promoted the Roman religion. With that aim, we will introduce the central features of the seviratus Augustalis, its main debated points, its presence throughout the Roman Empire and the particularities observed in Hispania.

\section{1.}

\section{General aspects of the seviratus Augustalis}

Studies about the seviratus Augustalis are plentiful. There have been numerous works and articles about this institution since the middle of the $19^{\text {th }}$ century. Different general studies have analysed the conditions of this institution in the whole Empire (Egger, 1844; Mourlot, 1895; von Premerstein, 1895; Taylor, 1914; Id. 1924; Nock, 1934; Oliver, 1958; Duthoy, 1978; Ostrow, 1985; Id. 1990; Abramenko, 1993; Castillo García, 2003; Mouritsen, 2006; Vandevoorde, 2015; Laird, 2015; van Haeperen, 2016), but there 
are also several books and papers about the existing sources concerning the seviri Augustales on a regional or local level, which have multiplied in the last decades. In the case of Hispania, we can mention some works about the entire Iberian Peninsula (Ciccotti, 1891; Étienne, 1958; Serrano Delgado, 1988; Arrizabalaga Lafuente, 1994; Jordán Lorenzo, 2004; Id. 2003-2005) as well as a selection of numerous articles centred in the Hispanic provinces of Baetica (Melchor Gil, 1994a; Id. 1994b), Hispania Citerior (Navarro Caballero, 1997) and Lusitania (Andreu Pintado, 1998).

The seviratus Augustalis was an institution of semi-official nature -meaning that it wasn't an official magistrature- which flourished in many Roman towns that had the status of coloniae and municipia. It appeared in Italy at the end of the $1^{\text {st }}$ century B.C. and spread throughout the Empire between 12 B.C. and the $3^{\text {rd }}$ century of the Common Era, becoming a typical institution of the provincial towns, mainly in the western and Latinspeaking part of the Roman Empire.

Concerning its internal organisation, it was a collegial institution with six annual members and an association of former members, with its own building and treasury. Its first term sevir refers to the number of members, meaning literally "six men". The term Augustalis, which derives from the title Augustus, shows a clear link with the emperor, and also with Imperial Worship, in the opinion of different researchers (e. g. Egger, 1844; Mourlot, 1895; von Premerstein, 1895; Taylor, 1914; Duthoy, 1978).

The seviri Augustales were appointed by the local ruling class of the decuriones and assumed some religious and civic functions, whose nature is under discussion. They had a higher status than common citizens and were also known as the group of the sevirales or Augustales. One of the main features of this institution was that its members were mostly wealthy freedmen whose wealth came from commercial and craft businesses in urban areas. This was their way to acquire official recognition, since the magistracies and priesthoods were forbidden to freedmen. In return, they had to fund many public donations, even more than the holders of local magistracies reserved to ingenui or freeborn people. 
The preserved sources about the seviri Augustales are basically epigraphic. Within the vast Roman literature, the sevirate is only mentioned in the story of the Cena Trimalchionis of Petronius (Petr. Satyr. 27-78) and in two brief allusions by two scholiasts of Horatius: Porphyrio (Porph. ad Hor. Sat. II, 3, 281) and Pseudo-Acro (Ps.-Acro, ad Hor. Sat. II, 3, 281). The long passage of Petronius contains rich and detailed information about the character and behaviour of the sumptuously rich freedman and sevir, Trimalchio, and it also mentions his friends Habinnas and Hermeros, who share his status and position. But the parodic purpose of this novel complicates the interpretation of the real characteristics of the institution. As to the two scholiasts, they make only brief and confusing comments about the function of the Augustales, indicating their priestly role but with certain mistakes that promote doubts about this aspect.

In contrast with the scarce literary sources, there are about three thousand inscriptions related to the seviri Augustales. Around two thousand of them are in Italy, and the other thousand belong to the territories of the Roman provinces.

In the following map (Figure 1) we can see the distribution of the evidence of the Augustality throughout the Roman Empire, with the number of certain inscriptions preserved in each province and Italic region. Their original area is Italy, with the highest concentration of inscriptions. Almost all of its regions have hundreds of inscriptions about the seviri Augustales, as we can see. We must clarify that the numbers for the Italic regions are not completely accurate. We include references to some seviri that could belong to the republican period or would have no connection with the Augustality, especially among the 242 cases in the northern Italic region of Transpadana / Regio XI. But the comparatively large number of Italic inscriptions illustrates the origin of the seviratus Augustalis, as well as the predominance of Latin epigraphy in Italy.

From the Italic towns, the institution spread to the provinces, principally to the Latin-speaking ones, in Europe. The most prolific provinces are Gallia Narbonensis, Hispania Citerior and Dalmatia, all of them located on the Mediterranean coast 
and well-connected to Italy. In relation to this, the South-East of Gallia, the Mediterranean area of Hispania and the provinces of the Illyricum contain most of the provincial inscriptions. The African testimonies are considerably fewer, whereas the Eastern, Greek-speaking part of the Empire has only scarce examples of these epigraphs.

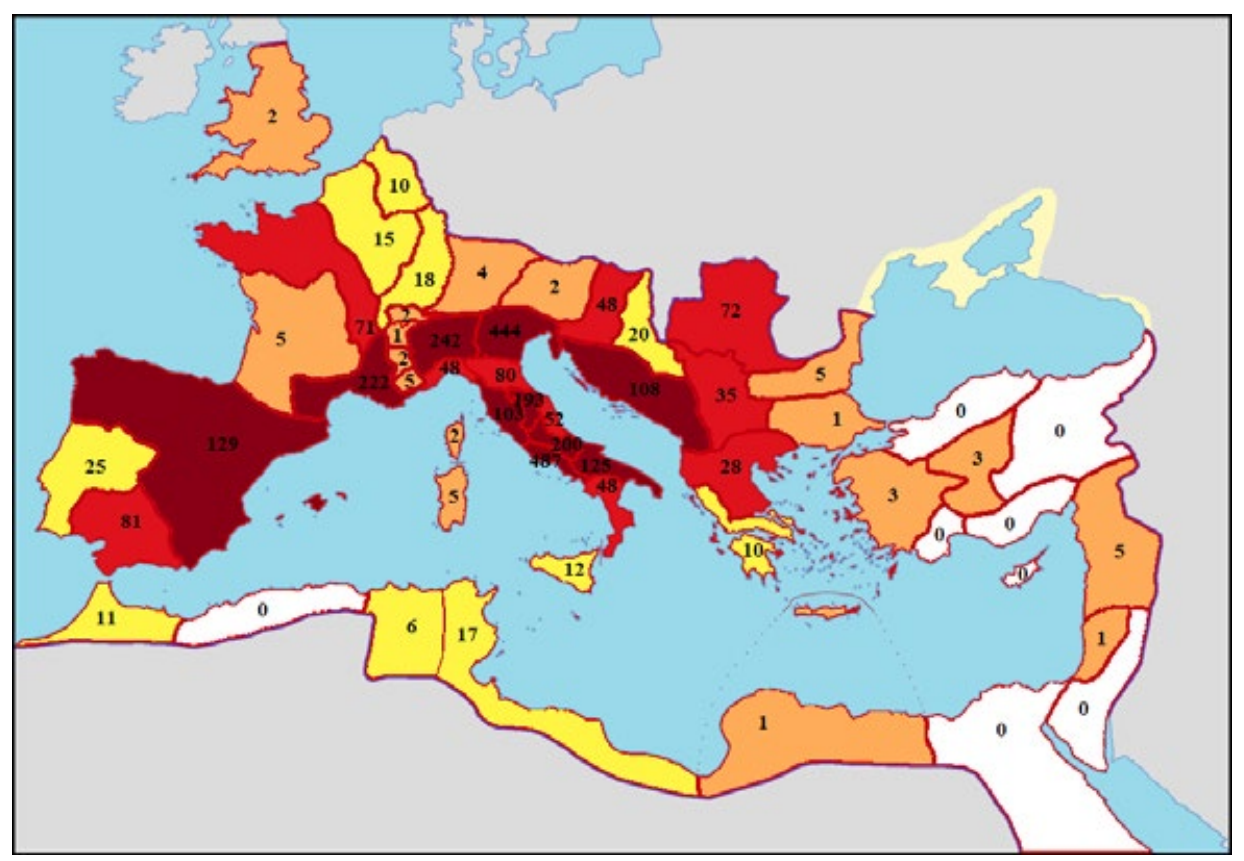

Figure 1. Provincial distribution of the inscriptions mentioning seviri Augustales. Edited from https://commons.wikimedia.org/wiki/File:Roman_Empire_in_120_AD.png

The three provinces of Hispania have a significant number of testimonies that testify to the importance of the seviratus $A u$ gustalis in this territory. They include around 250 inscriptions, a quarter of all the provincial cases in the Empire. Their internal distribution in the Hispanic provinces and their subdivisions of the conventus iuridici show the prominence of the South and the East of the Iberian Peninsula (Figure 2). That means the entire province of Baetica and the Mediterranean coast of Hispania Citerior-conventus Tarraconensis-, in contrast with the secondary role of the rest of this province and Lusitania. As an urban 
institution, the Augustality developed particularly in the more urbanized areas connected with trade routes by sea or by river. The most prosperous communities of freedmen lived in this kind of town, in places like Tarraco, Barcino, Corduba, Hispalis, Augusta Emerita and Carthago Nova. On the other hand, the central and Atlantic regions of Hispania had minor contacts with the main commercial networks and developed their urbanisation much less, so the seviri Augustales are exceptional there.

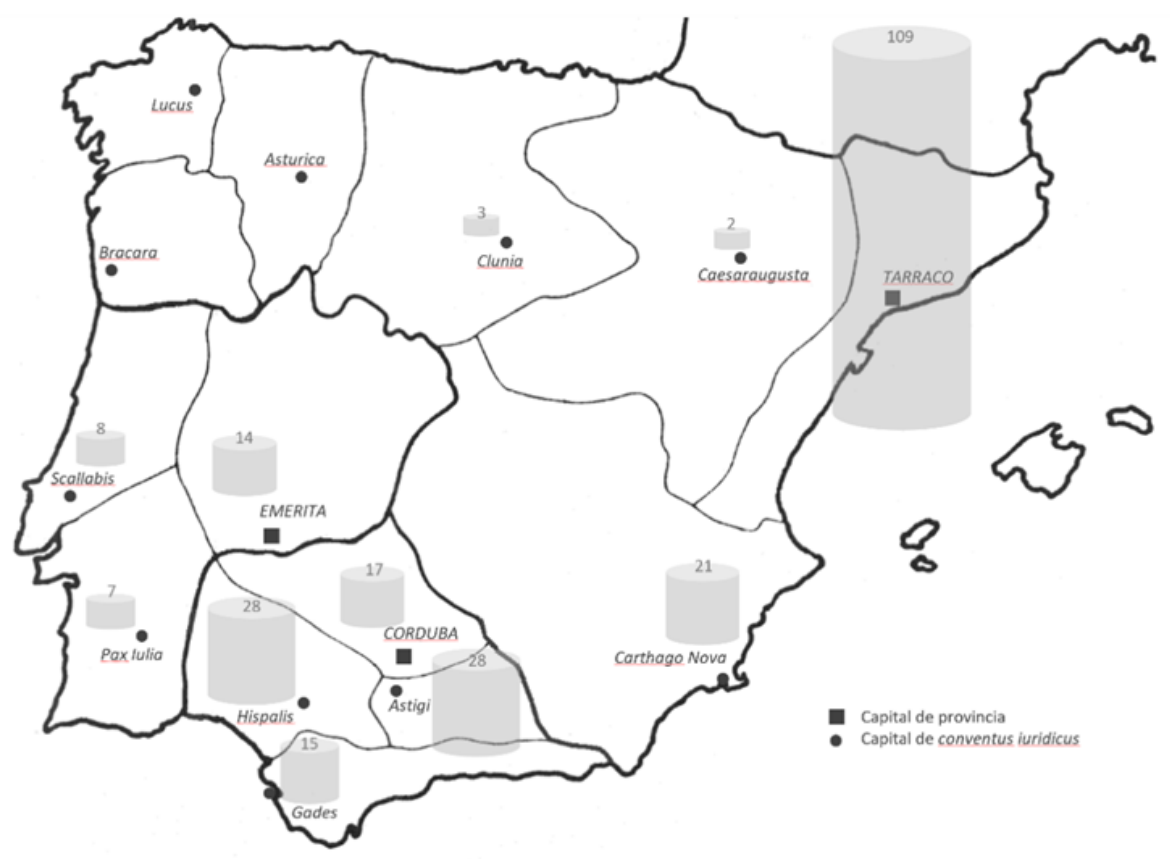

Figure 2. Distribution of the inscriptions about seviri Augustales among the Hispanic conventus iuridici (source: author).

The chronological evolution of the studied institution corresponds to the so-called "epigraphic habit", an expression that defines the evolution of the production of epigraphs during the Roman Empire (MacMullen, 1982; Mrozeck, 1973; Id. 1988; Meyer, 1990). The epigraphic habit shows a rising tendency in the $1^{\text {st }}$ century $\mathrm{AD}$, a peak in the $2^{\text {nd }}$ century and a sharp decline in the $3^{\text {rd }}$, due to transformations in the civic conscience and in the ways of public representation. Those changes were also related to a strong 
decrease in the number of freedmen, undermining the social basis of the seviratus Augustalis, which happened in the same period when epigraphy declined.

As an example of this process, we can see in the next table (Figure 3) the chronological distribution of the Hispanic inscriptions related to seviri Augustales. Excepting the case of Lusitania, where most of the inscriptions belong to the $1^{\text {st }}$ century, the evolution is as previously mentioned, with an increasing trend in the $1^{\text {st }}$ century and the most prolific point in the $2^{\text {nd }}$, before a sudden drop in the $3^{\text {rd }}$ century.

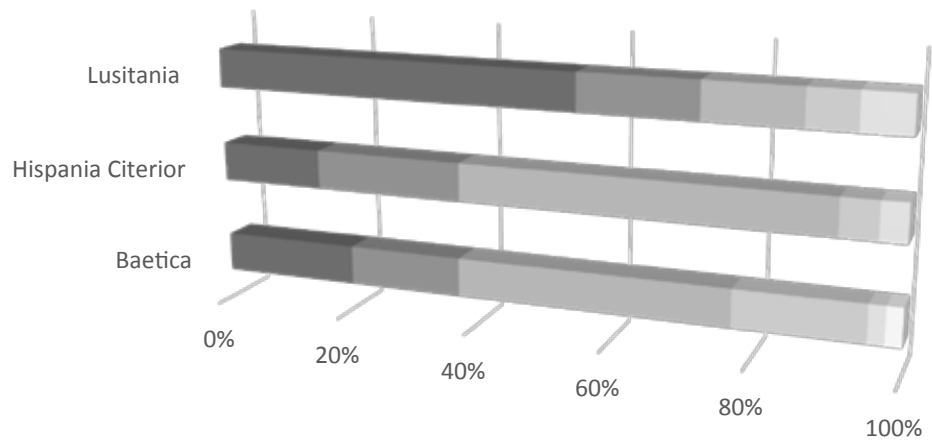

\begin{tabular}{|l|c|c|c|}
\hline \multicolumn{1}{c|}{} & Baetica & Hispania Citerior & Lusitania \\
\hline - I century & 18 & 21 & 16 \\
\hline I-II centuries & 15 & 30 & 5 \\
\hline II century & 35 & 72 & 4 \\
\hline II-III centuries & 16 & 7 & 2 \\
\hline III century & 2 & 5 & 2 \\
\hline Uncertain dating & 2 & 0 & 0 \\
\hline
\end{tabular}

Figure 3. Chronological distribution of the Hispanic inscriptions about seviri Augustales (source: author). 


\section{2.}

\section{Terminological variations}

One aspect that causes confusion about the seviratus Augustalis concerns its terminological variations. The epigraphic writing of the word sevir can appear in four different ways, depending on the mode of representing the number "six": IIIIIVir, VIvir, sevir or sexvir. The following table (Figure 4) shows the presence and distribution of testimonies in the three provinces of Roman Hispania, where the fourth of those variations does not appear. These only illustrate local epigraphic customs and don't imply any difference in the content of the seviratus.

\begin{tabular}{l|c|c|c|c|c}
\hline PROVINCES / WRITINGS & IIIIIIVIR & VIVIR & SEVIR & SEXVIR & TOTAL \\
Baetica & 23 & 34 & 16 & - & 73 \\
\hline Hispania Citerior & 70 & 27 & 45 & - & 142 \\
\hline Lusitania & 4 & 2 & - & - & 6 \\
\hline Total & 97 & 63 & 61 & - & 121 \\
\hline
\end{tabular}

Figure 4. Writing variations of the term sevir in the provinces of Hispania (source: author).

The variability is even higher regarding the ways of mentioning the institution. The next table (Figure 5) indicates the six variations present in Hispania. The main one by far is sevir Augustalis, followed by Augustalis, sevir and the regional expression honos seviratus, almost exclusively from Hispania. Despite regional differences that can be perceived even in the case of Hispania, the most common form in the whole Empire is sevir Augusta$l i s$, so we use it for convenience as a generic name to include all the other terms. There were even more words to call the seviratus Augustalis, especially in Italy, such as the relatively frequent title of magister Augustalis, and several variations from Augustalis adapted to the names of the following emperors -Tiberialis, Iulialis, Claudialis, Neroniensis, Flavialis, Titialis, Nervialis. This tendency stopped in the $2^{\text {nd }}$ century, when the terminology for the Augustality reached a higher homogeneity, restricted to the 
variants sevir Augustalis, Augustalis and sevir. After many studies looking for peculiarities that would explain the existence of different institutions (von Premerstein, 1895; Duthoy, 1978), the most reasonable interpretation is that they belonged to the same reality (Abramenko, 1993; Mouritsen, 2006). The Augustality spread in an improvised and decentralized way, by initiative of each town, so its names never had a complete uniformity.

\begin{tabular}{l|c|c|c|c|c|c|c}
$\begin{array}{c}\text { TERMS / } \\
\text { PROVINCES }\end{array}$ & $\begin{array}{c}\text { SEVIRAU- } \\
\text { GUSTALIS }\end{array}$ & $\begin{array}{c}\text { AUGU- } \\
\text { STALIS }\end{array}$ & SEVIR & $\begin{array}{c}\text { SEVI- } \\
\text { RALIS }\end{array}$ & $\begin{array}{c}\text { HONOS } \\
\text { SEVIRATUS }\end{array}$ & $\begin{array}{c}\text { SEVIRA- } \\
\text { TUS }\end{array}$ & TOTAL \\
\hline Baetica & 32 & 17 & 20 & 2 & 19 & - & 90 \\
\hline $\begin{array}{l}\text { Hispania } \\
\text { Citerior }\end{array}$ & 101 & 4 & 20 & 1 & 18 & 3 & 147 \\
\hline Lusitania & - & 23 & 4 & - & 2 & - & 29 \\
\hline Total & 133 & 44 & 44 & 3 & 39 & 3 & 266 \\
\hline
\end{tabular}

Figure 5. Different terms for the Augustality in the provinces of Hispania (source: author).

\section{3.}

\section{Function of the Augustality}

Due to the epigraphic nature of our sources and their usually concise content, it's difficult to define the concrete function of the seviratus Augustalis. It is currently under discussion, and it has become the biggest mystery about this institution. Traditionally, the seviri Augustales were considered priests of the Imperial Cult, due to the link of their title with the Roman emperors (Egger, 1844: 23-24; Mourlot, 1895: 9-37; von Premerstein, 1895: 824-856; Taylor, 1914: 232-241; Étienne, 1958: 275-279; Duthoy, 1978: 1293-1306; Kneissl, 1980; Fishwick, 1991: 609-616). Nevertheless, the epigraphic evidence does not confirm that idea. The priests of the Imperial Cult were the more prestigious flamines Augustales. The seviri Augustales have some religious elements as the second word of their title denotes, but they lack any priestly sign or any indication of what their secondary role in the worship 
of the emperors would be. The absence of positive proof in that direction has made the scholars of the latest generations orient their studies towards socioeconomic aspects of the institution (Ostrow, 1990; Abramenko, 1993; Vandevoorde, 2015; Laird, 2015 ) or even to deny that they had any religious role (Gradel, 2002: 228-231; Mouritsen, 2006: 240-242), but it must be said that there had been a minor tendency of sceptics about the religious functions of the seviri Augustales from the first generations of researchers (Mommsen, 1888: 454; Nock, 1934: 636; Oliver, 1958: 492-493).

On the contrary, there is plenty of proof about the public munificence of the seviri Augustales. Their evergetic donations to the local community were frequent and expensive: statues, religious offerings and temples, public buildings and infrastructure, ludic performances and competitions, sportulae or distributions of money and goods, banquets, et cetera. Different authors have suggested that financing these actions could have been the real purpose of the Augustality (Mouritsen, 2006: 247-248), and recently the religious and the civic theses have been reconciled, arguing that the seviri Augustales were in charge of the local Augustalia or ludi Augustales, consecrated to Augustus. By organizing and funding this festival, they would combine both civic and religious aspects (van Haeperen, 2016: 141-145).

\section{4. \\ Agents of Romanity}

It has always been said that the seviri Augustales were mainly freedmen. This servile background is confirmed by the epigraphy through the frequent mentioning of their freedman status and through their abundant Greek cognomina. Greek cognomina were typical of slaves in the Latin part of the Roman Empire, even if we should avoid making an automatic rule from this. Independently of their real homeland, it was quite common to give Greek names to slaves in Roman society. Despite their non-Roman origin, the seviri Augustales embraced the Roman customs and 
diffused them in the Hispanic territory. The analysis of the inscriptions reveals their adoption of Roman onomastics, accepting this essential aspect of Roman culture in order to integrate themselves in the local community. They used especially the tria nomina, often a mention of their former master, and rarely referred to the voting tribe.

Their motivation for this attitude was social mobility. Through the Augustality, they were reaching a higher status. Actually, the seviri Augustales were inspired by the local elite or ordo decurionum. They imitated the decuriones and tried to be recognized as a subordinated elite, an ordo of second level (Egger, 1844: 45-50; Mourlot, 1895: 86-90; Nock, 1934: 634-636; Oliver, 1958: 482-483; Duthoy, 1974: 151-154; Id. 1978: 1266-1289; Ostrow, 1985: 70-72; Abramenko, 1993: 11-57 and 144-154). There are no preserved cases of this is Hispania, but sometimes the seviri Augustales even used the word ordo or reproduced the actions of the ruling group, like pretending to promulgate decreta. This emulation of the decuriones illustrates a top-down process of acculturation that eventually influenced lower social groups as well. Besides that, the possibilities of promotion reinforced the stability of the social system and the acceptance and local implementation of Roman institutions (Ostrow, 1990: 368-375).

Furthermore, the constructions and spectacles funded by the seviri Augustales helped to diffuse these prestigious and impressive elements of the Roman culture in Hispania. There are numerous epigraphic references in Hispania - about 150 inscriptions - to their funding of temples, baths, public buildings, theatre performances and gladiatorial games, distributions of money and goods, testamentary donations, as well as banquets for the community such as cenae or epula (Figure 6). By performing these actions, often dedicated ob honorem seviratus, they acted as promoters of the Roman traditions and institutions. 


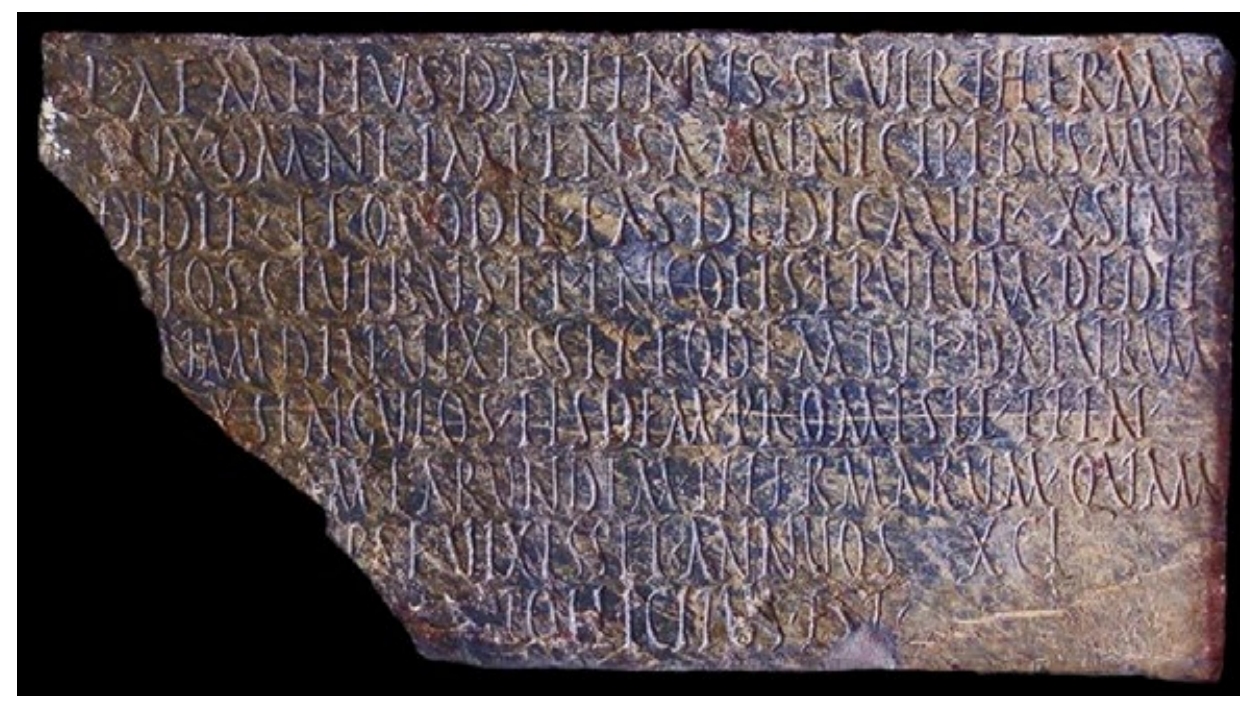

Figure 6. Inscription with a munificence consisting in public baths, a yearly contribution for its maintenance, distribution of money and a banquet, made by the sevir L. Aemilius Daphnus. CIL II, 5489 (Murgi, Baetica). Source: Hispania Epigraphica.

Roman religion was closely linked to the civic and political sphere, so these fields often mixed. Independently of their functions, the seviri Augustales contributed to the spread of Roman cults in Hispania through their offerings. In fact, their religious acts seem to have been more frequent than those of the local ruling class holders of the official priesthoods, as the comparison between the total inscriptions of the decuriones and the seviri Augustales in Hispania reveals. The table below (Figure 7) shows a much higher percentage of religious epigraphs from the latter group - almost $28 \%$ against $8 \%$ - despite the higher status and wealth of the former one. In Tarraco there is even the peculiarity that some seviri Augustales held the local priesthood of magister Larum, but this priestly feature has no parallel in the rest of Hispania.

Overall, the analysis of the religious dedications of the seviri Augustales exposes a clear majority of Roman divinities. Some of them were probably the result of a syncretism between Roman and local gods, but anyway the dominance of Roman divinities fits with the role played by the seviri Augustales in the acculturation 
of Hispania. They have only two offerings - out of 70 - that were made to certain native gods, and they are located in Lusitania, the furthest Hispanic province from Rome. One of them is dedicated to the gods Ana and Barraeca (Figure 8) and another one to dea Sancta Ataecina Turibriga Proserpina, whose name is syncretized with the Roman goddess Proserpina (HEp 5, 76).

\begin{tabular}{|c|c|c|c|c|}
\hline \multirow{2}{*}{ PROVINCE } & \multicolumn{2}{|c|}{$\begin{array}{c}\text { INSCRIPTIONS } \\
\text { OF THE SEVIRI AUGUSTALES }\end{array}$} & \multicolumn{2}{|c|}{$\begin{array}{l}\text { INSCRIPTIONS } \\
\text { OF THE DECURIONES }\end{array}$} \\
\hline & RELIGIOUS & TOTAL & RELIGIOUS & TOTAL \\
\hline Baetica & $32(36.4 \%)$ & 88 & 59 (14.7\%) & 402 \\
\hline Hispania Citerior & $29(21.5 \%)$ & 135 & $19(3.1 \%)$ & 606 \\
\hline Lusitania & $9(31 \%)$ & 29 & $14(9.7 \%)$ & 144 \\
\hline Total & $70(27.7 \%)$ & 252 & $92(8 \%)$ & 1152 \\
\hline
\end{tabular}

Figure 7. Comparison of the religious inscriptions of Hispanic seviri Augustales and decuriones.

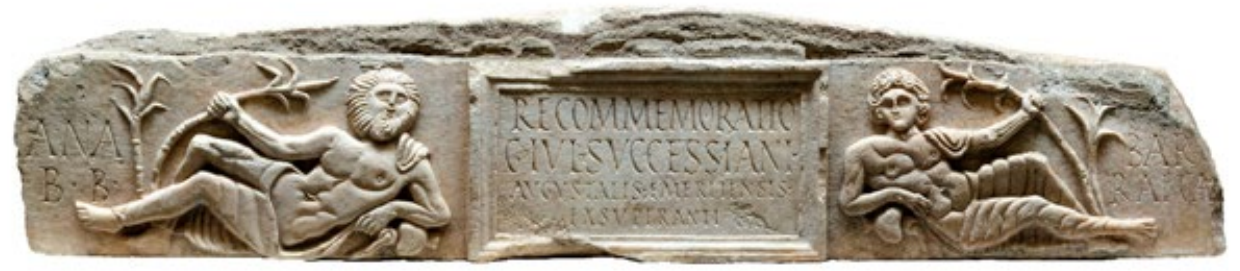

Figure 8. Lintel of the mausoleum of Caius Iulius Successianus, Augustalis, illustrated with the deities Ana and Barraeca. HEp 5, 105 (Augusta Emerita, Lusitania).

There are other patterns to the consecrations made by the seviri Augustales in Hispania that confirm them as promoters of Romanity. For example, two dedications were made to civic deities like de Genius of the town (CIL II, 1362 and 2069), emphasising the municipal identity. Many of them are consecrated to gods related with commerce, like Mercurius and Neptunus, as could be expected from the professional occupations of their dedicators. But the main aspect to note is their link with the imperial 
authority. Most of the offerings - 42 out of 70 - were made to deities who had the epithet Augustus or Augusta, 13 of them were dedicated to deified imperial virtues, and a few cases - only four - were consecrated directly to the emperor or a member of his family. This connection reflects the support of the Augustales to the imperial regime. The emperor was almost never in provincial towns, so there he was personified in the ceremonies of imperial worship. Through their private dedications, the seviri Augustales helped to make the power of the emperor more visible, to spread his fame and influence and to promote the belief in his divinity.

In conclusion, we consider that the studied institution wasn't only a dynamic platform for the social mobility of wealthy freedmen, but also a useful tool for the promotion of the Roman culture in Hispania. The seviri Augustales worked as agents of Romanity in different spheres, including the social customs, the local institutions and the religious practices of the population. As far as we can judge from what remains, they made a certain contribution to the further acceptance of Roman traditions and deities, to the stability of the society and to the strengthening of the imperial system.

\section{Bibliography}

Abramenko, A. (1993): Die munizipale Mittelschicht im kaiserzeitlichen Italien. Zu einem neuen Verständnis von Sevirat und Augustalität. Frankfurt: Lang.

AE - L'Année Epigraphique. Revue des publications épigraphiques relatives à l'Antiquité romaine. Collège de France, <París $>$, 1888-. Andreu Pintado, J. (1998): "Augustalidad, Sevirato y Evergetismo: aproximación a la promoción social de los libertos en Lusitania". Vipasca 7: 43-51.

Arrizabalaga Lafuente, I. (1994): “Seviros en Hispania”. Hispania Antiqua 18: 251-265.

Castillo García, C. (2003): Sevirato y augustalidad: un estamento intermedio en la vida ciudadana, in: J.F. Rodríguez Neila, C. Castillo García, F.J. Navarro Santana (eds.). Sociedad y economía en el occidente romano. Pamplona: Universidad de Navarra: 73-90. 
Ciccotti, E. (1891): "I sacerdozi municipali e provinciali della Spagna e gli Augustali nell'epoca imperiali romana”. Rivista di Filologia e di Istruzione Classica 19: 1-84.

CIL II - Hübner, E. (1869-1892): Corpus Inscriptionum Latinarum II: Inscriptiones Hispaniae Latinae. Inscriptionum Hispaniae Latinarum Supplementum. Berlin: Georg Reimer.

CIL XII - Hirschfeld, O. (1888): Corpus Inscriptionum Latinarum XII. Inscriptiones Galliae Narbonensis Latinae. Berlin: Georg Reimer.

Duthoy, R. (1978): Les Augustales. In: H. Temporini, W. Hasse (eds.). Aufstieg und Niedergang der Römischen Welt: Geschichte und Kultur Roms im Spiegel der neueren Forschung, II. Principat, 16, 2. Berlin-New York: De Gruyter: 1254-1309.

Duthoy, R. (1974): “La fonction sociale de l'augustalité". Epigraphica 36: 134-154.

Egger, A.E. (1844): Recherches sur les Augustales. Suivies des fragments du testament politique d'Auguste. Paris: Typographie de Firmin Didot Frères.

Étienne, R. (1958): Le culte impérial dans la Péninsule Ibérique d'Auguste à Diocletien. Paris: Boccard.

Fishwick, D. (1991): The Imperial Cult in the Latin West: Studies in the Ruler Cult of the Western Provinces. II, Part 1. Leiden: Brill. Gradel, I. (2002): Emperor Worship and Roman Religion. Oxford: Oxford University.

HEp - Hispania Epigraphica. Archivo Epigráfico de Hispania, Universidad Complutense, $<$ Madrid $>$, 1989-.

Jordán Lorenzo, Á.A. (2003-2005): “Epigrafía y labor colegial de la Augustalidad en la Península Ibérica”. Arys 6: 113-127.

Jordán Lorenzo, Á.A. (2004): Algunas reflexiones en torno a la distribución geográfica de Augustales en la Península Ibérica, in: J. Alvar Ezquerra, L. Hernández Guerra (eds.). Jerarquías religiosas y control social en el mundo antiguo. Actas del XXVII Congreso internacional GIREA-ARYS IX (Valladolid 7-9 de noviembre 2002). Valladolid: Universidad de Valladolid: 337-345.

Kneissl, P. (1980): "Entstehung und Bedeutung der Augustalität. Zur inschrift der ara Narbonensis (CIL XII, 4333)". Chiron 10: 291-326. 
Laird, M.L. (2015): Civic Monuments and the Augustales in Roman Italy. New York: Cambridge University.

MacMullen, R. (1982): "The Epigraphic Habit in the Roman Empire". American Journal of Philology 103: 233-246.

Melchor Gil, E. (1994a): El mecenazgo cívico en la Bética. La contribución de los evergetas a la vida municipal. Córdoba: Universidad de Córdoba.

Melchor Gil, E. (1994b): "Ornamentacion escultórica y evergetismo en las ciudades de la Bética”. Polis 6: 221-254.

Meyer, E.A. (1990): "Explaining the Epigraphic Habit in the Roman Empire: The Evidence of Epitaphs". Journal of Roman Studies 80: 74-96.

Mommsen, T. (1888): Römisches Staatsrecht. Vol. III. Leipzig: Hirzel.

Mouritsen, H. (2006): "Honores Libertini: Augustales and Seviri in Italy”. Hephaistos 24: 237-248.

Mourlot, F. (1895): Essai sur l'Histoire de l'augustalité dans l'Empire Romain. Paris: Libraire Émile Bouillon.

Mrozek, S. (1973): "À propos de la répartition chronologique de inscriptions latines dans le Haut-Empire". Epigraphica 35: 113-118.

Mrozek, S. (1988): "À propos de la répartition chronologique de inscriptions latines dans le Haut-Empire”. Epigraphica 50: 61-64.

Navarro Caballero, M. (1997): "Les dépenses publiques des notables des cités en Hispania Citerior sous le Haut-Empire”. Revue des Études Anciennes 99: 109-140.

Nock, A.D. (1934): "Seviri and Augustales". Annuaire de l'Institut de Philologie et d'Histoire Orientales et Slaves (Mélanges Bidez) 2: 627-638.

OED - Oxford English Dictionary, Third Edition (November 2010). [online resource]

Oliver, J.H. (1958): “Gerusiae and Augustales”. Historia 7: 472-496.

Ostrow, S.E. (1985): "Augustales along the bay of Napoles: a case for their early growth". Historia 34: 64-101.

Ostrow, S.E. (1990): “The Augustales in the Augustan Scheme", in: K.A. Raaflaub, M. Toher (eds.). Between Republic and Empire: Interpretations of Augustus and His Principate. Berkeley: University of California: 364-379. 
Petronius, Satyricon - C. Díaz y Díaz (1968): Petronio: El Satiricón (2 vols.). Barcelona: Alma Mater.

Porphyrio, ad Horatii satiras - A. Holder (1894): Pomponi Porphyrionis commentum in Horatium Flaccum. Innsbruck: Wagner.

Pseudo-Acro, ad Horatii satiras - O. Keller (1902-1904): Pseudoacronis scholia in Horatium vetustiora. Leipzig: Teubner.

Serrano Delgado, J.M. (1988): Status y promoción social de los libertos en la España romana. Sevilla: Universidad de Sevilla.

Taylor, L.R. (1914): “The Augustales, Seviri Augustales and Seviri: A Chronological Study". Transactions and Proceedings of the American Philological Association 45: 231-253.

Taylor, L.R. (1924): "Seuiri Equitum Romanorum and Municipal Seuiri: A Study in Pre-Military Training among the Romans". Journal of Roman Studies 14: 158-171.

Vandevoorde, L. (2015): "Of Mice and Men. Financial and Occupational Differentiation among ${ }^{\star}$ Augustales”. Cahiers Mondes Anciens 7: 2-24.

Van Haeperen, F. (2016): "Origine et fonctions des augustales (12 av. n.è. - 37). Nouvelles hypothèses". L'Antiquité Classique 85: 127-155.

Von Premerstein, A. (1895): Augustales, in: E. De Ruggiero (ed.). Dizionario epigrafico di antichità romane, I. Roma: L Pasqualucci: 824-877. 